\title{
Problems of foreign service and diplomacy in the post-Soviet context: the case of Armenia
}

\section{Vahram Ter-Matevosyan \& Anna Drnoian}

To cite this article: Vahram Ter-Matevosyan \& Anna Drnoian (2021): Problems of foreign service and diplomacy in the post-Soviet context: the case of Armenia, Third World Quarterly, DOI: 10.1080/01436597.2020.1866529

To link to this article: https://doi.org/10.1080/01436597.2020.1866529

\section{Published online: 22 Jan 2021.}

Submit your article to this journal $\sqsubset$

Q View related articles ¿

View Crossmark data [ 


\title{
Problems of foreign service and diplomacy in the post-Soviet context: the case of Armenia
}

\author{
Vahram Ter-Matevosyan (D) and Anna Drnoian (D) \\ Political Science and International Affairs, American University of Armenia, Yerevan, Armenia
}

\begin{abstract}
The institutional development of many post-Communist countries remains a daunting task. Since the early 1990 s, some of them have managed to achieve visible results in eradicating corruption and enhancing the effectiveness and accountability of public institutions, while others still struggle with several systemic problems. Since regaining its independence Armenia has managed to transform some of its public institutions by carrying out large-scale reforms; however, much remains to be done. The present research examines the institutional features of Armenia's Ministry of Foreign Affairs (MFA) before the 2015 constitutional amendments, which changed the semi-presidential system of government to parliamentary democracy. It particularly looks at the MFA's effectiveness in policy planning and formulation, its relation to the presidential administration, its recruitment strategies and the promotional prospects of the diplomatic staff. The study argues that for the past decade or so the impact of the MFA on foreign policy decisions has been limited, whereas the evaluation of recruitment and career promotion policies reveals several significant systemic deficiencies. Existing research on post-Soviet states concentrates mainly on diverse foreign policy and geopolitical problems and rarely pays attention to institutional considerations. The present research aims to address this gap.
\end{abstract}

\section{ARTICLE HISTORY}

Received 5 April 2020

Revised 5 December 2020

Accepted 11 December

2020

\section{KEYWORDS}

Armenia

foreign policy

diplomacy

institutional development

foreign service

\section{Introduction}

The countries in the post-Soviet space embarked on different paths of institutional development. Some of them were rather successful in modernising public administration systems, swiftly leaving behind the Soviet legacy of totalitarianism, while the reforms in other countries were hindered by domestic instabilities, civil wars, regional conflicts and resource-related constraints. Peculiarities of institutional and societal structures, power dynamics and administrative traditions coupled with regime types and bureaucracy models should be considered, too, when examining the reasons for the sluggish reforms in public administration systems. One complex public institution that differs from others in terms of its functions, objectives and deliverables is the Ministry of Foreign Affairs (MFA). Yet the foreign policy of post-Soviet countries has not been studied from an institutional perspective (with the exception of Russia), ie in terms of the structure and functions of the MFA, its 
resource allocations, the organisation and evaluation of the diplomatic missions, and the training of future diplomats. The present study aims to contribute to the existing literature on post-Soviet institutional transformations by discussing the structural and practical shortcomings of Armenia's foreign service. The diplomatic service of Armenia is the key executor of the country's foreign policy, ${ }^{1}$ and its effective organisation and functioning are of significance for promoting national interests abroad.

The study evolves around the following questions: Does the MFA contribute to foreign policy formulation (proactive component), and if so to what extent, or does it perform purely executive and coordinative functions? Does the MFA possess a system of foreign policy planning mechanisms? What are the major instruments and principles for the recruitment and advancement of the diplomatic personnel? The argument of this essay is twofold: (1) the impact of the MFA on foreign policy formulation and planning has been rather limited; (2) for some time, the MFA has suffered from significant deficiencies in its recruitment, career promotion and rotation practices. In chronological terms, the study provides an assessment of Armenia's foreign service during the first term of Serzh Sargsyan's presidency (2008-2013). The first five years of his tenure are chosen because the period is indicative of his leadership style and decision-making pattern, which is consistent with his second term. Occasionally, some parallels and comparisons are made with the functioning of the MFA during Levon Ter-Petrosyan's (1991-1998) and Robert Kocharyan's (1998-2008) administrations.

The study does not underestimate the impact of systemic, structural and proximate factors on the institutional development of the country's foreign policy. The geopolitical challenges faced by Armenia, such as the conflict in Nagorno-Karabakh, its closed border with Turkey, and polarisation of integration processes - its membership in the Eurasian Economic Union and attempts to complement the dependence on Russia by increased cooperation with the European Union - cannot but affect significantly the way the foreign policy is conducted. ${ }^{2}$ Although this research generally falls into the field of foreign policy analysis constituting part of the more generalist international relations studies, it focuses particularly on the impacts of bureaucratic politics and the interaction of government players on the eventual foreign policy choices made, since the study aims to explain the foreign policymaking capacity of the MFA, which constitutes a stable and permanent bureaucracy.

The article has the following structure: after presenting the methodology, the prior research on the subject is summarised to provide the framework and context for the present study. Then, formal authorities vested in the laws and the political leadership towards the MFA are delineated. Finally, the actual diplomatic practice, recruitment strategies and policymaking instruments of the MFA are examined.

\section{Research methodology}

The research methodology is qualitative, based on content analysis of secondary and primary data, the latter collected through semi-structured interviews with former high-ranking diplomats. The secondary data analysis involves an examination of laws and presidential and government decrees - which set the legal framework of the diplomatic service - as well as annual reports and further available data regarding the foreign policy service published by the MFA and the Commission on Ethics of High-Ranking Officials of Armenia. 
Face-to-face interviews were designed as this research method allows gathering in-depth data directly from the stakeholders involved in the foreign policy-making process. A key informant sampling technique was used, and former ambassadors as well as MFA senior staff knowledgeable about the subject matter were contacted with an interview request. The initial objective was to aggregate insights from diplomats serving during Serzh Sargsyan's presidency and those whose experience spanned earlier administrations. However, the diplomats on duty proved hesitant when approached to discuss the institution's efficiency, and this is considered a major limitation of the present research. Specifically, the heads of the following departments at the MFA were contacted for interviews: Policy Planning Department, Human Resources Department, Department of Culture and Humanitarian Cooperation, Commonwealth of Independent States (CIS) Department, Department of the Americas, and the International Organizations Department. Interviews were conducted throughout March and April 2014, with an average duration of an hour and a half.

The interviews were transcribed, and a pre-defined 'coding map' was used to organise the collected data and interpret its meaning. The descriptors developed and used for categorising data correspond to the research questions as laid out in the introduction. For that reason, the content analysis is incorporated in the respective parts of the subsections dealing with the MFA's structure, policy planning/formulation versus policy implementation capacity, the role of the presidential administration versus MFA, and institution and recruitment/ professionalism of diplomats.

\section{Foreign service in the new age: varying expectations}

This section aims to set a contextual framework for the examination of Armenia's foreign service by considering the following questions: How has globalisation affected the diplomatic practices of (small) states? What forms and practices should be adopted in dealing with the pressing foreign policy challenges? The diplomatic environment of the twenty-first century is marked by change and volatility. The new diplomatic order is characterised by (1) an extended scope and pace of international events affecting states; (2) an expansion in the number and variety of international actors (civil society organisations (CSOs) and transnational corporations (TNCs)); (3) the growing involvement of regional organisations; (4) a shift in preoccupation from primarily traditional issues of high politics to a wide range of pressing low politics (economic, cultural, environmental concerns, pandemics); (5) the interconnection between foreign and domestic policy; (6) a renaissance of geopolitics as states compete for resources and influence; and (7) fragmentation of the rules and norms governing international political and trade relations. ${ }^{3}$ The reform environment of diplomatic institutions is a result of increased involvement and expectations of citizens in foreign agenda formulation, and advancements in communications and technology, with subsequent changes in the responsibilities of diplomats. ${ }^{4}$ In light of these transformations, John Robert Kelley argues that the state does not have a monopoly on diplomacy anymore and diplomats are facing an incredible decline. 'Diplomacy's statist tradition', he continues, 'once the bedrock organizing institution for pursuing international politics, is ceding influence to non-state actors - the "new" diplomats - who have displayed impressive skills at shaping policy through means that foreign ministries fail to grasp.' 5 There are, however, opposing views acknowledging that certain parts of the foreign policy agenda have indeed been outsourced to other actors, while arguing that 'the range and importance of diplomacy did not shrink, but rather expanded'. 
Changing patterns of conflict and cooperation and the progressive erosion of hierarchies in a transformational age have challenged foreign policy and the traditional tool to manage its goals - diplomacy. ${ }^{7}$ Foreign policy, as a result, has acquired different features. Kishan Rana, for instance, anticipates the twenty-first century to be a century of globalised diplomacy due to paradigmatic changes in the way international relations are conducted. Specifically, the shift towards globalised diplomacy is determined by the growing significance of public diplomacy with the prioritisation of culture, science, technology and consular work as well as the multiplicity of groupings, many of which are based on the geographic principle. ${ }^{8}$ Public diplomacy can be defined as the efforts of a government to influence public opinion in other countries through establishing channels of communication with certain audiences. Clifford Malone sees the core notion of public diplomacy to be that of 'direct communications with foreign peoples, with the aim of affecting their thinking and, ultimately, that of their governments. ${ }^{9}$ These domains, which were formerly the exclusive reserve of professional diplomats, are now diversified, involving various stakeholders.

In light of the changing diplomatic environment, public diplomacy scholarship highlights the following transformations within the foreign service and the new forms of diplomatic representation: (1) integration between the ministries and diplomatic missions abroad, which acquired more power because of the multiplicity of international issues that needed to be tackled; (2) restructuring of the traditional departmental organisation to cope with new policy domains; (3) change in the location and strategy of the diplomatic missions abroad, and replacement of the embassies in accordance with the growing priority regions; (4) usage of different modes of diplomatic accreditation, specifically coverage by the same ambassador of several countries within the region, shared 'co-location' or 'joint ambassadorship' with a friendly state; (5) the openness of foreign affairs to public engagement; (6) simultaneous multiple representations or cross accreditation; and (7) virtual embassies, integrating online monitoring of countries and periodic visits. ${ }^{10}$

Personnel are also crucial to the functioning of the diplomatic service. Scholars largely focus on recruitment issues (appropriate methods and required skills) and buildup of foreign service officers. Hocking et al. ${ }^{11}$ recommend that personnel with the proper profile should possess traditional skills (knowledge of linguistics and history) as well as new abilities (networking and social media). Moreover, foreign service personnel should advance their knowledge in strategic planning and geopolitical analysis. ${ }^{12}$ The literature, however, has rarely addressed the level of satisfaction of foreign service officers. As a result, a set of questions remains beyond the scope of various foreign policy and management systems analysis: How are the basic interests of foreign service officers defended? How does the performance of their duties correlate to their compensation? Why, for most of them, does overseas service remain one of the key coveted incentives to stay in the system?

Post-Soviet Eurasian states inherited their structure and history/experience from the Soviet Ministry of Foreign Affairs, but they started to pursue different, and frequently conflicting, policy agendas from the day they proclaimed independence. Sergey Minasyan elaborates on the issue:

Western-oriented, foreign policy prevails in Georgia, Ukraine, and Moldova; with some reservations Kazakhstan, Belarus and three of four existing de-facto states (Abkhazia, North Ossetia, and Transnistria, but not Karabakh) have pursued a pro-Russian policy; while Armenia, Azerbaijan and the rest of the Central Asian states try to balance the often incompatible 
interests of regional players including Russia, the United States, Europe, Turkey and China (in [the] case of Central Asian states)..$^{13}$

Post-Soviet Eurasian states are similar in their consolidated authoritarian, semi-authoritarian or hybrid regimes, which tend to grant a person (the president or prime minister) the gatekeeper's role between domestic and international affairs. This centralisation of power diminishes the role of institutions, and makes them dysfunctional and even more bureaucratised. It is important to assert next that 12 of the 15 post-Soviet countries - leaving the Baltic States aside - experienced various encounters with democratisation which largely shaped, reshaped and redefined the challenging interplay of power dynamics. In 12 post-Soviet countries, democratisation was not a linear process. In the end, five of these 12 post-Soviet countries have not transferred power to opposition through elections, and the remaining seven states have had a diverging record in maintaining democratic achievements.

Our contextual analysis reveals that foreign ministries persist in playing a central role in the protection of post-Soviet states' interests overseas, despite some transformations currently under way in international relations as a result of various dynamics. In the light of the ever-changing operational environment, the public diplomacy scholarship highlights the need to transform the modes of diplomatic practices and organisational structure to overcome various intrinsic deficiencies in current foreign policymaking systems. Regardless of state capabilities (eg small, developing, etc.), scholars highlight the role of policy planning and evaluation as well as reasonable resource allocation in designing effective foreign policy. A successful design is rooted in careful cost-benefit analysis, and scrutiny of the available evidence and alternatives. In brief, all the stages of the foreign policymaking cycle should be constantly reconsidered based on the evaluation of and adaptation to the lessons learnt.

\section{Legal framework and practical competencies of Armenia's MFA}

'... for a small country like Armenia, which confronts such big challenges, the diplomacy is not only the front but the first line of attack.14

This section lays down the priorities, formal authorities and actual capabilities of the Armenian diplomatic service. Since Armenia gained independence in 1991, the foreign policy priorities of Armenia have evolved around a few objectives: peaceful resolution of the Nagorno-Karabakh conflict; worldwide recognition of the Armenian Genocide, particularly since the late 1990s; normalisation of its relations with neighbours, mainly Turkey; and strengthening of Armenia's security through active participation in international cooperation and integration platforms. ${ }^{15}$ Some of these items came to occupy a significant place in the foreign policy agenda of President Sargsyan's first term in office: (1) attempted normalisation of relations with Turkey, (2) intensification of negotiations with Azerbaijan over the Nagorno Karabakh conflict, ${ }^{16}$ (3) enhanced cooperation with Russia in the economy and security sectors and the president's abrupt decision to join the Russian-led Eurasian Economic Union on 3 September 2013; and (4) the implementation of a number of reforms to meet the criteria for initiating an Association Agreement with the European Union (EU). ${ }^{17}$ Domestic political considerations, including the legacy of the debacle of 1 March (when 10 people were killed in the streets of Yerevan in the wake of the highly contested 2008 February presidential 
elections), played no secondary role in shaping Sargsyan's foreign policy agenda during the first term in the office. Another moment overshadowing his term and relations with the MFA was the incident on 24 February 2008, when some 10 high-ranking and experienced diplomats, including ambassadors, were dismissed from their positions and stripped of their diplomatic rank. The reason for this was that they had signed a petition protesting the voting irregularities during the presidential elections held 5 days earlier. ${ }^{18}$ Roughly half of these diplomats either left the country, did not return to Yerevan or became engaged in politics. By engaging in various foreign policy initiatives, Sargsyan hoped not only to alter the domestic political discourse but also to revamp Armenia's tarnished reputation in the eyes of influential external actors.

These policies and political priorities set the context in which president Sargsyan had to build his foreign policy, and the MFA was to operate between 2008 and 2013. In addition, the MFA became an early target to carry out institutional reforms, aiming at enhancing the effectiveness of the ministry. This reform-oriented agenda of the MFA was in line with President Sargsyan's election platform, which aimed at implementing what he framed as 'second generation of reforms'. Two out of six components of the reform agenda were about Armenia's foreign and security policy as well as enhancing the efficiency of public administration. ${ }^{19}$ A study of documents and analysis of political statements reveals that, despite outlining a reform agenda assigned to the MFA, the presidential administration retained unilateral decision-making privileges.

During the Soviet period, the Armenian Soviet Socialist Republic (SSR) had its own MFA, like all 15 Soviet republics. The MFA had a small staff and a limited area of activity. The agents, structure and objectives of Armenia's MFA completely changed with the proclamation of its independence in September 1991. During the following two decades, Armenia has established diplomatic relations with 157 countries and joined 87 international organisations. As of 2014, there were 61 Armenian diplomatic missions abroad, and 58 diplomatic missions of foreign countries and international organisations in Armenia. ${ }^{20}$

The MFA, as a state executive body, elaborates and implements state policy in foreign affairs under the general leadership of the president of Armenia, as well as manages the diplomatic service. ${ }^{21}$ The MFA is also a leading coordinating body of the executive branch in the spheres of building and developing relations with foreign states and international organisations. It supervises the activities of other agencies in the international arena and exercises general control over the implementation of Armenia's international obligations. ${ }^{22}$ The goals and duties of the MFA, as prescribed by government decrees, include (1) developing the foreign policy concept of Armenia, submitting foreign policy-related recommendations to the president and the government, and implementing the foreign policy adopted by the country; and (2) strengthening the role of Armenia in overcoming global and regional challenges. ${ }^{23}$

As far as the distribution of authority is concerned, foreign policy is the president's domain. According to article 55.7 of the constitution, which remained in force until 2018, the president represents Armenia in international relations, guides foreign policy, and concludes or suspends international agreements or forwards them to the National Assembly for ratification. ${ }^{24}$ Moreover, the presidential order of 2010 assigned an even greater role in the formulation and supervision of foreign policy to the presidential administration. ${ }^{25}$ In particular, it stipulates that: (1) the representatives of the presidential administration should be invited to the discussions of the diplomatic missions' work plans held by the Deputy Minister of Foreign 
Affairs and by the respective departments of the MFA; and (2) the representatives of the presidential administration should participate in the discussions of the preliminary conclusions of the MFA's annual reports. ${ }^{26}$ The same presidential order established the system for planning, evaluation and monitoring of diplomatic missions, which gave a substantial role to the Office of the President of Armenia and the staff of the National Security Council. ${ }^{27}$ The presidential order can be examined from two perspectives: (1) it was in line with Sargsyan's 'second generation of reforms' as discussed above; and (2) it reflected his mindset and leadership style and effectiveness in exercising the power of the office. To use a categorisation of leadership styles, Sargsyan falls into 'the magisterial method' of governing, where 'the president places himself as the authoritative head of the government' which, in turn, implies a'concentric-circle approach [which] places the president at the center of the national security policy process.'28

Constitutional and legal provisions provide a clear distribution of roles and areas of responsibility. However, during the policy planning, implementation and evaluation phases one can observe shortcomings of the institutional development, as well as intra-elite shaky relations, tensions between the executive and legislative branches and, more importantly, the complexity of decision-making in a political system with a powerful chief executive and a set of other factors. This article is not intended to discuss all of these components; rather, it aims to focus only on the MFA. All interviewees asserted that the MFA's policy planning and agenda-setting capacity has remained largely underdeveloped. A former diplomat argued that in spite of legal provisions, the MFA lacked analytical capabilities and primarily reacted to external challenges, instead of anticipating them and formulating alternative scenarios. ${ }^{29}$ The reason for this claim could be attributed to at least three factors: tradition, a shortage of human resources, and management issues. Another retired diplomat suggested that the mechanism of foreign policy formulation should start with the analysis and planning performed by the ministry and its diplomatic missions, then move up to the presidential administration, where proposals will be reconsidered and will set the background for the decisions. Only then would these policy decisions be subject to MFA's implementation. ${ }^{30} \mathrm{An}$ other interviewee affirmed that even though the ministerial staff do not have the capacity to conduct research and implement policy at the same time, the ministry does not cooperate with other educational and research institutions that analyse foreign policy issues either. ${ }^{31}$ However, since 2012 the foreign minister has been holding regular meetings with the leading foreign policy experts and scholars of Armenia to discuss pressing foreign policy issues. These experts represent Armenian universities, the National Academy of Sciences, government and independent think tanks and various non-governmental organisations. The meetings were aimed at exchanging opinions about foreign policy problems and communicating the government's position on some of these issues.

Sargsyan's presidential administration has indeed been profoundly involved in foreign policy related issues. Since 2011, the Chief of Staff of the President's Administration, Vigen Sargsyan (note that despite the shared last name there is no familial relationship between the two), has coordinated numerous projects (the Armenian Genocide Centennial Committee, for instance); participated in negotiations on the resolution of the Karabakh conflict; made frequent statements on foreign policy issues (on Armenian-Turkish relations, for instance); and been actively involved in international organisations (as President of the CIS Council of Humanitarian Cooperation). Most famously, after Armenia's president decided to join the Russia-led Eurasian Economic Union on 3 September 2013 - a step which was interpreted 
as a U-turn in Armenia's four-year-long process of intensive negotiations to sign the Association Agreement with the European Union - it was Vigen Sargsyan who reacted to the flow of critical remarks and gave an interview to Radio Liberty the following day. His remarks thus preceded the foreign minister's first statements. ${ }^{32}$ Vigen Sargsyan's experience in the presidential administration was quite extensive, hence his interest in foreign policy. He was the aide to Armenia's second president, Robert Kocharyan, between 2003 and 2008, coordinating the matters of foreign policy, and then served in the same position in Serzh Sargsyan's administration for one year. In 2009 he was promoted to Deputy Chief of Staff and in 2011 he became the Chief of Staff.

Early in his term, during a meeting with diplomats in 2008, Serzh Sargsyan voiced his dissatisfaction with the activity level of the diplomatic service, which reflected his expectations of diplomats: 'We see a tendency of wait-and-see, not acting based on own initiatives and not assuming responsibilities. This approach cannot bring success to the Republic of Armenia.'. ${ }^{33} \mathrm{He}$ urged the diplomatic missions to take more responsible actions in the political and economic domains, which could be assessed using measurable indicators within a reasonable period. Besides stressing the need for constant evaluation, the president also argued in favour of policy planning and analysis and proceeded to refer to diplomats as 'the highest level of planning in foreign relations.' In particular, he urged them to rely on evidence-based and informed policy: 'you should be equipped with maps, statistical data, and argumentations.34 In August 2011, during the third meeting with the senior staff of the MFA and the heads of the Armenian diplomatic missions abroad, Sargsyan asked them to be fighters on the diplomatic front lines:

Always remember that you are soldiers too, standing at the front line. The Armenian nation waits for your success .... I wish you, the moving force of our independent state's diplomacy, be [sic] more confident, vigorous, enthusiastic, and aim-oriented, ready for new diplomatic battles and victories. ${ }^{35}$

In June 2014, Sargsyan once again laid out his expectations from the diplomats:

A diplomat should be able to thoroughly examine, analyze and assess the situation, forecast future developments, and offer solutions stemming from national interests. We often mention that human capital is the most valuable resource. Thus, an expectant [sic] and reactive diplomat who dodges his responsibilities is a luxury for a state like ours. We expect you to be actively engaged in all the areas in which Armenia and Armenians have direct or indirect interests. ${ }^{36}$

In March 2012, the Armenian government decided to dub 2 March, the day when Armenia became a member of the United Nations (UN) in 1992, as the'Day of the Republic of Armenia (RA) Diplomat'.37 In his statement on that anniversary, on 2 March 2014, Foreign Minister (FM) Nalbandyan ${ }^{38}$ gave the following qualitative assessment of the MFA's performance:

... today Armenia's stance on the important issues to its foreign policy agenda is more audible at different international arenas, and the country is perceived to be a reliable partner, which pursues balanced foreign policy on both bilateral and multilateral forums. ${ }^{\prime 39}$

However, the minister did not elaborate on Armenia's reliability in foreign affairs, particularly in light of the president's last-minute turnabout regarding the Association Agreement with the EU. ${ }^{40}$

An analysis of various statements of the president and the FM suggests that both the president and the minister invested efforts to institutionalise the diplomatic service and to improve its standing. Indeed, their statements demand effective management of diplomatic 
personnel and expansion of the capacity to deal with the emerging challenges Armenia is facing. However, as will be shown later in this article, some informal practices and career promotion decisions contradicted the previous statements, which turned out to be merely rhetorical. Moreover, some sluggish actions and inadequate responses to pressing international issues in the period under consideration reveal that a gap remains between the objectives set for institutional development and the actual results. ${ }^{41}$

\section{Diplomacy in action: expanding external relations}

This section outlines diplomatic activities in the period under consideration. It also examines diplomatic appointments in respect to their professional eligibility and effectiveness for the promotion of national interests abroad. The main activities of the MFA and the objectives set by the president are recorded in the annual reports. The annual reports of the MFA, as well as FM Nalbandyan's statements on the ministry's activities, support the argument that Armenian diplomacy has been active during the period under consideration. Although the number of foreign visits made by the president gradually decreased (from 22 in 2009 to 15 in 2013), FM Nalbandyan's foreign visits increased from 29 in 2009 to 48 in 2013. Similarly, fewer heads of state/government arrived in Armenia on an annual basis (dropping from eight to three over the same period), whereas foreign ministers of various countries visited Armenia more often (increasing from 16 to 22).

Since 2008, Armenia has opened several embassies and consulates in geographically diverse countries (see Table 1). In this regard, FM Nalbandyan argued:

there are no important and unimportant countries in the world .... We must try to develop our relations with all the states, and that is the aim of our diplomacy. One cannot limit its vision [sic] only to the regional issues in the 21 st century; we conduct multi-vector, initiative-based and active policy. ${ }^{42}$

Comparing the locations of the newly opened embassies with the approximate statistics available on the Armenian diaspora worldwide shows that many diplomatic missions have

Table 1. Diplomatic missions opened since 2008 (Source: Presidential Decrees and the Annual Reports of the MFA).

\begin{tabular}{lcll}
\hline Country & Opening date & Diplomatic mission & Residency \\
\hline 1. France & 2013 & Consulate & Marseille \\
2. France & 2013 & Consulate & Lyon \\
3. United Mexican States & 2013 & Embassy & Mexico City \\
4. Sweden & 2013 & Embassy & Stockholm \\
5. Indonesia & 2013 & Embassy & Jakarta \\
6. Holy See (Vatican City State) & 2013 & Embassy & Rome \\
7. Vietnam & 2013 & Embassy & Hanoi \\
8. International Organization of the Francophonie & 2013 & Permanent Mission & NA \\
9. Ukraine & 2012 & Consulate & Odessa \\
10. Denmark & 2011 & Embassy & Copenhagen \\
11. Czech Republic & 2011 & Embassy & Prague \\
12. Lithuania & 2011 & Embassy & Vilnius \\
13. Netherlands & 2010 & Embassy & The Hague \\
14. Japan & 2010 & Embassy & Tokyo \\
15. Iraq & 2010 & Embassy & Baghdad \\
16. Brazil & 2010 & Embassy & Brazil City \\
17. Spain & 2010 & Embassy & Madrid \\
18. Kuwait & 2010 & Embassy & Al Kuwait \\
\hline
\end{tabular}


been established in countries where the Armenian population does not exceed 40,000 (for instance, Japan, Kuwait, Vietnam, Indonesia, etc.). In 2013 alone, Armenia established diplomatic relations with five states (Vanuatu, Myanmar, Swaziland, Uganda and Mauritius). ${ }^{43}$ The opening of embassies in countries with small or limited Armenian populations can have two explanations. On the one hand, that move stresses the importance that the MFA attributes to these countries as essential players in international politics. The government of Armenia sought to deepen its cooperation with these countries not only in the spheres of culture, education and science, but also in terms of international organisations. More importantly, the expansion of diplomatic missions can also be interpreted as Armenia's efforts to work with countries that previously supported Azerbaijan's resolutions in various international platforms, and where Azerbaijani diplomatic missions have been particularly active.

Other objectives included attraction of Foreign Direct Investments (FDIs) from these countries, especially in the cases of Kuwait, Sweden and Japan, and development of the tourism industry. An additional expectation was that these countries would reciprocate and open embassies in Armenia. However, only two of them opened diplomatic missions in Armenia. The opening of consulates in Armenian-populated communities in Odessa (Ukraine), Marseilles (France) and Lyon (France) followed a different logic since it aimed at increasing contacts with local Armenians. Working with the Armenian diaspora had occupied an important part of Sargsyan's presidency. He established the Ministry of Diaspora in 2008 and continuously highlighted the importance of close collaboration between the diaspora institutions abroad and Armenia. He was particularly hopeful that the assistance from the diaspora, which has been the case for the past decades, should be transformed into mutually beneficial cooperation. He did not, however, hide his expectations that the diaspora will also invest in Armenia's economy, which had a hard time recovering from the 2008-2009 global financial crisis. Opening consulates in Ukraine and France should be analysed from that perspective, too.

\section{Achievements and pitfalls in empowering the diplomatic service}

One of the notable goals of Sargsyan's administration was to improve the professionalism of the Armenian diplomatic service. Founding a diplomatic school was a noteworthy step undertaken in that direction. President Sargsyan met with the senior executive staff members of the MFA and the heads of the Armenian diplomatic missions abroad in 2008, 2009, 2011 and 2014. An analysis of the president's speeches reveals foreign policy goals and the president's expectations from the diplomats. During the first meeting in September 2008, Sargsyan shared his concerns about the existing administration of the diplomatic service: 'It is extremely disquieting that there are many vacancies in the ministry, and the competition does not yield sufficient results. It is strange that there is little demand for this rather interesting and attractive profession. ${ }^{44} \mathrm{He}$ also suggested establishing a diplomatic school as a possible way of solving the existing recruitment problem. The school was opened in 2009. In the next few years, hundreds of young people applied for admission. Although the Diplomatic School admits a small number of students and its programme lasts only nine months, it plays an important role in enriching the diplomatic service with motivated young men and women and improving diplomatic professionalism.

Article 24 of the Law on Diplomatic Service defines the terms of appointment to the positions of the diplomatic service. Thus, only RA citizens who hold a higher education 
degree corresponding to the requirements of a given position, speak the Armenian language, and have a knowledge of no less than two foreign languages can be assigned to a diplomatic service. Though no document prescribes the minimal level of education and experience required for an appointment to discretional positions, Article 18.1 of the Law on Diplomatic Service indicates that diplomatic ranks reflect qualifications that correspond to professional knowledge and work experience. The law then defines the Ambassadors Extraordinary and Plenipotentiary as well as the Envoys Extraordinary and Ministers Plenipotentiary as the highest diplomatic ranks, thus implying that they should satisfy the highest requirements regarding their knowledge and skills.

An examination of the profiles of the ambassadors who were appointed or reappointed by President Sargsyan's decrees ${ }^{45}$ from April 2008 until April 2014 shows that all have a higher education degree, but about half of them (24 out of 49 ) do not have any educational background in Diplomacy, international relations, or a related subject. Of the 49 appointments and reappointments, 38 (78\%) were career diplomats. ${ }^{46}$ In addition, Vahan Hovhannisyan had experience in parliamentary diplomacy, and Michael Minasyan ${ }^{47}$ had represented another country in Armenia as Consul General. ${ }^{48}$ On the other hand, nine had no prior experience in diplomacy and came from such fields as the legislature (two), judiciary, presidential administration (two), government, science and research, and - more remarkably - business and entertainment.

The president explained during the 2009 meeting with Armenian diplomats that he had already appointed 10 ambassadors, two of whom were political nominees without prior experience in diplomatic service. Sargsyan stated: 'I want to view diplomatic work as a professional activity, the cornerstones of which are your professional qualities and dedication to Armenia, not to a person.'49 However, since 2009 political nominees have been increasingly appointed as ambassadors.

Appointments to diplomatic positions for various political purposes (to reconcile with the opposition or to provide service to politicians who had resigned or retired from highlevel positions) have been another concern raised by the political opposition and media. Thus, Vahan Hovhannisyan, a deputy representing the opposition party Armenian Revolutionary Federation (ARF-Dashnaktsutyun) at the National Assembly, ${ }^{50}$ was appointed as an Ambassador Extraordinary and Plenipotentiary to Germany. ${ }^{51}$ The appointment of the former Prime Minister Tigran Sargsyan as an ambassador to the United States on 3 April 2014, weeks after his resignation, is another compelling example. ${ }^{52}$ Tigran Sargsyan was heavily criticised in Armenia for the poor economic performance of the country, whose reputation was also damaged after his name was circulated in a notorious offshore scandal. The former leadership of Nagorno Karabakh has also benefitted from political appointments in the diplomatic service. For instance, Oleg Yesayan, the former Prime Minister and former Speaker of the National Assembly of Nagorno Karabakh, was appointed as RA ambassador to Russia. Arkadi Ghukasyan, the first FM of Nagorno Karabakh and then its third president (1997-2007), was appointed as special envoy. Sargsyan's brother, Levon Sargsyan, Armenia's former ambassador to Lebanon, was also appointed as special envoy in 2010.

Appointments of two celebrities - with no previous experience in diplomacy - as ambassadors raised even more questions. In 2009, Charles Aznavour, a world-renowned FrenchArmenian singer, was appointed as Ambassador to Switzerland and Permanent Representative to the UN Offices and other international organisations in Geneva. Another surprising move was to appoint Youri Vardanyan, a gold medallist in weightlifting at the 1980 Moscow Olympic Games and an iconic figure in the Soviet Union, as ambassador to Georgia. After 
returning from the United States in 2009, where he had lived for more than 20 years, Vardanyan was appointed as Sargsyan's advisor, then served as Minister of Sports and Youth Affairs for one year in 2013, after which he was appointed as ambassador.

The rationale behind some of those appointments came to be questioned in the mass media. Interviewees of the present research also looked at these appointments with a certain skepticism, out of concern for the professionalism of the MFA. One of them, who was also appointed to an ambassadorial position as a political appointee during Levon Ter-Petrosyan's tenure, asserted that although non-career diplomats can be useful for the promotion of the country's foreign policy objectives, it is very important for a diplomat to possess the skills for diplomatic work. Specifically, the appointee must be able to write diplomatic letters, provide accurate reports, know the appropriate diplomatic demeanour and ethics, and be knowledgeable about the culture and traditions of the host country. ${ }^{53}$ Furthermore, one of the interviewees argued, 'diplomacy is a step-by-step work' and has its own rules and tricks that cannot be acquired in a short time. The same interviewee asserted that holding a high-ranking diplomatic position has become a matter of prestige for the Armenian oligarchy. ${ }^{54}$ This assessment raises some questions about the degree to which some protocols are effectively enforced. By legislation, a diplomat who has a stake of $10 \%$ or more in the authorised capital of any commercial organization is obliged to put it in a trust within a month after the appointment to foreign service. ${ }^{55}$ Besides, at least in theory, Armenian diplomats are not allowed to be involved in another paid job, except an academic one.

Concerns are also voiced in public forums. For instance, the former Deputy Foreign Minister Arman Navasardyan, Armenia's former ambassador to Austria and Lebanon, noted that political appointments have'disturbed many professionals in the Ministry, who accumulated years of experience to get promoted ..., but they only see how people with no connection to the diplomacy [sic] are promoted'. He went on to claim that the existing appointment practices are'dangerous, pernicious and defective. ${ }^{\prime 6}$ Another experienced diplomat, Ruben Karapetyan, Armenia's former ambassador to Egypt and Italy, was even more critical towards these political appointments. He argued that there is no foreign policy; hence, 'no objectives are assigned to diplomats; and, therefore, it does not matter who leads Armenia's diplomatic missions.'57

Overall, the interviews revealed that the former diplomats were overwhelmingly critical towards the MFA. Their experience (both personal and professional) led them to believe that the MFA was not able to cope effectively with the foreign policy challenges facing Armenia. However, it should be added that some parts of the criticism were not backed by sufficient evidence and lacked coherence. There is no evidence that the interviewees raised their concerns about the institutional crisis while they were in diplomatic service. Also, they did not address the question of how to develop the institutional foundations of the MFA in the future.

The conflict of interest between business and diplomacy is another aspect that deserves attention. The link is well exemplified if the declared wealth of the ambassadors is examined. The richest diplomats came from business (Andranik Manukyan, ${ }^{58}$ Murad Muradyan ${ }^{59}$ ), the presidential administration (Michael Minasyan, Arsen Shoyan ${ }^{60}$ ) and the parliament (Vladimir Badalian $^{61}$ ). One of the Armenian billionaires in the Russian Federation, the Chairman of the Board of Directors of 'RESO-Garantia' (a major Russian insurance company), Sergei Sarkisov, was appointed Armenia's Consul General in Los Angeles. ${ }^{62}$ His brother, Nikolay Sarkisov, was appointed Consul General in Lyon, upon the opening of that consulate in December 2013. Such appointments support the speculation that some of these individuals pursue their business interests while serving abroad. The political opposition in Armenia has heavily criticised 
the engagement of businessmen in diplomacy, and some representatives of the diaspora communities have raised similar concerns. There have been continuous objections about the intrinsic conflict of interests of businessmen-turned-diplomats. Complaints from some of the Armenian communities indicated a lack of professionalism and the limited contact that the political appointees maintained with local diaspora institutions. In some cases, however, the businessmen covered the embassy or consulate expenses, for instance in the Vatican, Denmark, and Los Angeles, thereby decreasing the MFA budgetary allocations. This claim is based on personal conversation with the people close to ambassadors and consul generals.

Against this background, two pertinent questions arise: What is the relationship between the ambassadors' professional background and their productivity? Do career diplomats have a better record of performance than non-career ones, or political appointees? The literature on foreign service and diplomacy suggests that while diplomats should be skilled in persuasion, analysis, communication and languages, the job does not necessarily require experience in the diplomatic service, as non-career diplomats may have equally important qualities and social contacts to contribute to their professional success, such as creativity and connections with the country's political elite.

A study by Kopp and Gillespie ${ }^{63}$ quantifies the optimal amount or ratio of career diplomats versus political appointments. The authors emphasise that during J. F. Kennedy's tenure, the ratio of career diplomats to non-career diplomats in the United States was 2 to 1, which subsequently became the prevailing norm. ${ }^{64}$ Another study, conducted by J. M. McCormick, ${ }^{65}$ shows that the appointments of non-career ambassadors from the Kennedy administration to the Clinton administration ranged from $33 \%$ to $24 \%$.

The logic behind some of Armenia's ambassadorial appointments reveals a peculiar pattern. For instance, Armenia has resident ambassadors in seven of the 15 post-Soviet republics. Between 2008 and 2013, with the exception of Armenia's ambassadors to Kazakhstan and the Baltic states, ${ }^{66}$ all were political appointees. One way to explain this pattern and answer the above questions might be attributed to Serzh Sargsyan's conviction that in the post-Soviet space, with its distinct political culture, regime types, and level of institutional developments, political appointees had a better track record of communication with the ruling elite of the resident countries. Their experience in building informal networks, to Sargsyan, would prove to be more efficient than of career diplomats.

While a separate study must be conducted to evaluate the performance of Armenian diplomatic missions, it is worth mentioning that the inflow of FDI to Armenia has drastically decreased since 2008. In the post-Soviet space, Russian companies top the list of investors in Armenia, while the FDIs from other post-Soviet countries remain insignificant. Since 2009, a performance evaluation of each Armenian embassy has not been an integral part of the annual reports submitted by the MFA. Hence, evaluating the individual performance of all ambassadors remains an elusive task. However, the record from the post-Soviet countries, where most of the ambassadors were political appointees, suggests that at least in the economic sphere their performance was not impressive.

The length of service in diplomatic missions raises other questions. Article 12 of the Law on Diplomatic Service stipulates that the position of Ambassador and Permanent Representative can be assigned for a period of up to four years. After the expiration of that term, ambassadors can be directly appointed to another country or international organisation for up to three years or can return to Yerevan for a few years. In 2013, Hetq.am, a platform for investigative journalism, published an article to show how Article 31.2 of the 
corresponding law was regularly violated by the diplomatic service. The latter limits appointment to diplomatic positions abroad to two years, with a possible extension of one year, but the fact is that many diplomats hold a given diplomatic assignment for four to six years. In 2018, an observer pointed out several examples of such violations. ${ }^{67}$ Vigen Chitechyan served in France (1995-1997, 2009-2018), Benelux countries (1997-2009), Monaco, Andorra (2011-2018), and the Holy See (2012-2013) for more than 20 years in total. Arshak Poladian spent 16 consecutive years abroad: served as an ambassador to the United Arab Emirates (2002-2006), Kuwait, Bahrain (2003-2007), Syria (2007-2018), and Jordan (2011-2018). Armen Martirosyan is abroad from 2003 until now (Permanent Representative of Armenia to the United Nations (2003-2009), Ambassador to Germany (2009-2013), India (since 2015), and South Asian countries with a residence in New Delhi. Ararat Gomtsyan has been Armenia's Consul General in the Southern Federal District of the Russian Federation (Rostovon-Don) for 11 years since 2004. Envoys to the UN, Belarus, Lebanon, USA, Russia, Brazil, and Tajikistan during the first term of Serzh Sargsyan's presidency (2008-2013) were already posted abroad for more than seven years. No justifications have been provided for these long tenures.

\section{Conclusion}

This article has demonstrated the institutional challenges in Armenian foreign policy and diplomacy over the past decade. It has revealed a set of structural and procedural limitations to conducting efficient foreign policy in'a century of globalized diplomacy' - in the words of Kishan Rana. The reviewed literature suggests that states need to adopt paradigmatic changes in the rapidly changing diplomatic environment. In the twenty-first century, the rules and practices of international politics have changed to align and promote the interests of more stakeholders than previously. Problems of foreign service and diplomacy identified in the text are not unique to Armenia. Since the collapse of the Soviet Union, many countries have gone through similar or identical challenges, where autocratic and corrupt practices hindered modernisation and reforms of public institutions. The research showed that a transition to democratic statehood and the process of institutional change require innovative forms of governance in which newly embedded organisational and institutional models prevail. Continuous strengthening of accountable and transparent public institutions will also visibly decrease the inertia and political conformity in the foreign service and boost institutional modernisation and innovation.

Based on an analysis of RA legislation, official statements made by the RA president and FM, annual reports, and in-depth interviews with former high-ranking diplomats, this study concludes that during Serzh Sargsyan's first term, the impact of the MFA on foreign policy decisions was rather limited, despite his claims of the opposite. In fact, the MFA, as an executor and coordinator of the foreign policy priorities outlined by the president, played a fairly limited role in foreign policy planning and agenda-setting processes in the early stages of the policymaking cycle, whereas the presidential administration of the RA played a preponderant role in foreign policy.

The examination of Armenia's foreign service during Sargsyan's first term has also revealed significant deficiencies in the recruitment and management of the Armenian diplomatic corps. This article identifies the following shortcomings with regard to the appointment to the highest diplomatic ranks: (1) a growing selection of envoys from business and political circles; and (2) a tendency to appoint retired politicians, celebrities and 
family members to represent Armenia abroad. Furthermore, regular violations of the rotational principles are damaging the effective functioning of the foreign service. The launching of the Diplomatic School within the MFA was a major step in recruiting capable young people and training diplomats. Although the presidential decree of 2010 introduced a system to evaluate the performance of the MFA and its diplomatic missions abroad, working monitoring mechanisms have yet to be developed to enhance the productivity of Armenia's foreign service.

The 2015 constitutional amendments transformed Armenia into a parliamentary democracy, which implies that the role of the parliament and the executive branch is significantly expanded at the expense of presidential power. Sargsyan's election as Prime Minister in April 2018, after his second term as president expired, resulted in a series of anti-government protests in Armenia from April to May 2018. Large-scale demonstrations and rallies forced Sargsyan to resign just six days after his election, and Nikol Pashinyan, a journalist turned politician, was elected as PM on May 8. Since May 2018, the MFA has gone through some reforms. One of the visible changes since 2018 has been the fact that all the newly appointed ambassadors have been career diplomats. A consequent development was the closing of the embassy in Denmark - opened in 2011 - which merged with the Armenian embassy in Sweden. A new diplomatic move was the restoration to the foreign service of some diplomats who were fired in February 2008, or who left the service between 2008 and 2018 due to disagreements and conflicts. In the end, the MFA should also undertake some structural changes, as the current institutional set-up does not reflect the global trends in foreign service practices. The challenges that Armenia faces in the twenty-first century require critical rethinking of the traditional foreign policy and diplomacy models.

\section{Acknowledgements}

The authors would like to thank the anonymous reviewers for their valuable comments on earlier drafts of this paper.

\section{Disclosure statement}

No potential conflict of interest was reported by the authors.

\section{Notes on contributors}

Vahram Ter-Matevosyan, DrPhil from University of Bergen, is an Associate Professor and Chair of the Political Science and International Affairs Program at the American University of Armenia (AUA). He specialises in the history, and foreign, and security policies of Armenia and Turkey. His most recent monograph is Turkey, Kemalism, and the Soviet Union: Problems of Modernization, Ideology and Interpretation (New York \& London: Palgrave Macmillan, 2019). His research has been published in edited volumes by Routledge and Springer, and in peer-reviewed journals such as Nations and Nationalism, Europe-Asia Studies, Turkish Studies, Middle Eastern Studies and Eurasian Geography and Economics.

Anna Drnoian is a Senior Research Analyst at Synopsys and a Teaching Associate at AUA. She has an MA degree in political science and international affairs from AUA. She has written on Armenia's foreign 
policy and problems of institutional development. Her most recent article appeared in Eurasian Geography and Economics.

\section{Notes}

1. "Law on Diplomatic Service of the RA, 2001."

2. The new EU-Armenia Comprehensive and Enhanced Partnership Agreement (CEPA) was signed in the margins of the Eastern Partnership Summit on 24 November 2017. The CEPA did not include the deep and comprehensive free trade agreement (DCFTA), and many saw it as compromise between the 2013 association agreement and Armenia's new commitments after accession to the Eurasian Economic Union.

3. Hocking et al., Futures for Diplomacy; Moses and Knutsen, "Inside out"; Rana, 21st Century Diplomacy.

4. Rana, Foreign Ministries.

5. Kelley, "New Diplomacy: Evolution of a Revolution."

6. Kleiner, "Inertia of Diplomacy."

7. Lane, "Modernising the Management of British Diplomacy."

8. Rana, 21st Century Diplomacy, 13-4.

9. Mueller, "New Perspectives on Public Diplomacy," 90.

10. Rana, Foreign Ministries, 6-7; Hocking et al., Futures for Diplomacy, 6.

11. Hocking et al., Futures for Diplomacy, 75.

12. Ibid., 7.

13. Minasyan, "Multi-Vectorism in the Foreign Policy."

14. Oskanian, Ankakhutyan Chanaparhov, 12.

15. For more about the continuities and ruptures of Armenia's foreign policy in the 1990 and 2000s, see Papazian, "From Ter-Petrosyan to Kocharian"; Ter-Petrossian, Armenia's Future Relations with Turkey; Ter-Petrossian, "Entrani: Yeluytner, hodvatsner, hartsazruytsner"; Libaridian, Challenge of Statehood; Shougarian, Does Armenia Need a Foreign Policy?; Kocharyan, Zhizn'i Svoboda.

16. In the period under consideration, the Armenian president has met with his Azerbaijani counterpart at least 18 times to find a solution to the Nagorno Karabakh conflict. For more on this see Caspersen, "South Caucasus after Kosovo."

17. German, "Securing the South Caucasus"; Delcour, "Between the Eastern Partnership and Eurasian Integration"; and Ter-Matevosyan et al., "Armenia in the Eurasian Economic Union."

18. Shougarian, "We Have Not Resigned."

19. "Serzh Sargsyani nakhyntrakan tsragiry" ["The Election Platform of Serzh Sargsyan"].

20. Ministry of Foreign Affairs of the Republic of Armenia, Embassies, "Diplomatic Directory, 2013."

21. "Law on Diplomatic Service of the RA, 2001," Article 7, Amended 11.06.04.

22. The Decree of the President of the RA on the Coordination of the Common Foreign Policy of the RA Executive Bodies, 2000, $1^{\text {st }}$ clause, Arlis.am; and "Law on Diplomatic Service of the RA, 2001," Article 7, Paragraph 2, 3, Amended 11.06.04.

23. RA Government Decision No. 1245-N, 2002, Addendum No. 1, Article 7.

24. The Constitution of the Republic of Armenia.

25. RA President Order NK-107-N, Addendum 1.2.

26. Ibid., Addenda 1.6, 2.4, 3.16.

27. Ibid.

28. Sarkesian, Williams, and Cimbala, US National Security, 17, 73.

29. Interviewee No. 2.

30. Interviewee No. 3.

31. Interviewee No. 1.

32. "Armenia Still Hopes for EU Agreement."

33. President.am, Press Releases, "Statement of President Sargsyan at the Gathering of the MFA."

34. Ibid. 
35. President.am, Statements and Messages of the President of the RA, "Excerpts from Serzh Sargsyan's Address."

36. Ministry of Foreign Affairs of the Republic of Armenia, Press Releases, "Consultations of Senior Officials of MFA."

37. RA Government Decree No 325-N on Marking the Day of the Diplomats, 2012, Arlis.am.

38. Eduard Nalbandyan, Armenia's FM between 2008 and 2018, was a graduate of Moscow State University of International Relations. He started his diplomatic career in 1978 as an attaché in the embassy of the Soviet Union in Lebanon, then he worked at the Soviet MFA. After the SU disintegration, he became an Armenian diplomat serving as Armenia's ambassador to Egypt and France.

39. Ministry of Foreign Affairs of the Republic of Armenia, Press Releases, "Statement of the Minister of Foreign Affairs."

40. Armenia had been negotiating the Association Agreement with the European Union for more than three years and the Deep and Comprehensive Free Trade Agreement for about two years before the 3 September presidential announcement about joining the Russian-led Customs Union.

41. For instance, Ramil Safarov, an Azerbaijani officer who murdered Armenian officer Gurgen Margaryan during the North Atlantic Treaty Organization (NATO) training session in Hungary in 2004, was extradited to Azerbaijan in August 2012. He received a hero's welcome in Baku and was pardoned by Aliyev. Armenia's Ambassador to Austria, Arman Kirakosyan, whose task was to monitor the ongoing developments of the Safarov case in Hungary, had failed to prevent it.

42. Ministry of Foreign Affairs of the Republic of Armenia, "Press Conference, Answers of the Minister of Foreign Affairs."

43. Ministry of Foreign Affairs of the Republic of Armenia, Report on the Activities of the Ministry of Foreign Affairs.

44. President.am, Press Releases, "Statement of President Sargsyan at the Gathering of the MFA."

45. Ambassadors and permanent representatives are appointed and dismissed by the President of the RA ("Law on Diplomatic Service of the RA 2001," amended on 11.06.04 No. 106-N, 22.12.10 No. 28-N, article 12).

46. These include those who went through all the diplomatic ranks in the MFA, as well as those who had been political appointees during Kocharyan's tenure and had acquired diplomatic experience prior to their re-appointment by Sargsyan (for example, Oleg Yesayan).

47. Michael Minasyan was President Sargsyan's son-in-law. From 2007 to 2008, he was a senior aide to then-Prime Minister Serzh Sargsyan. After Sargsyan's election as president, Minasyan became the First Deputy Chief of Staff of the President. In 2013, he became Armenia's ambassador in Vatican.

48. Vahan Hovhannisyan had experience in parliamentary diplomacy. In particular, he led the first delegation of the National Assembly of Armenia in NATO's Parliamentary Assembly in 1999. From 2003 to 2008, he was the head of Armenia's parliamentary delegation to the Organization for Security and Cooperation in Europe (OSCE) Parliamentary Assembly and the co-chair of the Armenia-Russia and Armenia-Belarus inter-parliamentary committees. Michael Minasyan was the Honorary General Consul of the Republic of San Marino in Armenia from 2005 to 2013.

49. President.am, Statements and Messages of the President of the RA.

50. In 2009, the ARF left the coalition government it had formed with the Republican Party and Prosperous Armenia Party since 2007 and became an opposition party.

51. It is believed that he was appointed to that position to continue his cancer treatment in Germany. He passed away in December 2014.

52. "Ex-Prime Minister Tigran Sargsyan Will Go."

53. Interviewee No. 2.

54. Interviewee No. 4.

55. "Law on Diplomatic Service of the RA, 2001," amended on 11.06.04, No. 106-N, 22.12.10 No. 28$\mathrm{N}$, article 44.1 (a), 44.3.

56. Harutyunyan, "Dilettantism Raises Its Head."

57. Karapetyan, "Diplomacy without Foreign Policy."

58. Andranik Manukian was severely wounded during the October 1999 terrorist attack in the Armenian parliament. Later, he was appointed Minister of Transport and Communication, then 
Advisor to the President. He was in the construction business. In April 2012, he was appointed as Armenia's ambassador to Ukraine.

59. Murad Muradyan, founder and chairman of the Moscow-based BAMO construction company, was appointed Armenia's ambassador to Iraq in September 2010.

60. Arsen Shoyan was the head of the Analytical Research Department at the Office of the President. He was appointed Armenia's ambassador to Bulgaria in January 2010.

61. Vladimir Badalyan, an Member of Parliament (MP) in the National Assembly between 2003 and 2008, was appointed Armenia's ambassador to Turkmenistan and Tajikistan in 2008 and 2009, respectively.

62. "Businessperson Sergey Sarkisov is Armenia's New Consul General."

63. Kopp and Gillespie, Career Diplomacy, 51.

64. Ibid.

65. McCormick, American Foreign Policy and Process, 391.

66. Armenia's resident ambassador in Lithuania simultaneously covers Estonia and Latvia.

67. Sargsyan, "Violations of Law in Foreign Ministry."

\section{ORCID}

Vahram Ter-Matevosyan (ID http://orcid.org/0000-0002-2212-0391

Anna Drnoian (D) http://orcid.org/0000-0003-2741-7052

\section{Bibliography}

"Armenia Still Hopes for EU Agreement." Radio Liberty, 2013. https://goo.gl/MmSEDL

"Businessperson Sergey Sarkisov Is Armenia's New Consul General to LA." Asbarez.com, 2017. https:// goo.gl/nNZMPK

Caspersen, Nina. "The South Caucasus after Kosovo: Renewed Independence Hopes?" Europe-Asia Studies 65, no. 5 (2013): 929-945. doi:10.1080/09668136.2013.805959.

Delcour, Laure. "Between the Eastern Partnership and Eurasian Integration: Explaining Post-Soviet Countries'Engagement in (Competing) Region-Building Projects." Problems of Post-Communism 62, no. 6 (2015): 316-327. doi:10.1080/10758216.2015.1057075.

"Ex-Prime Minister Tigran Sargsyan Will Go to Diplomatic Service." Radio Liberty [in Russian], 2017. https://goo.gl/prxMqw

German, Tracey. "Securing the South Caucasus: Military Aspects of Russian Policy towards the Region since 2008." Europe-Asia Studies 64, no. 9 (2012): 1650-1666. doi:10.1080/09668136.2012.718418.

Harutyunyan, Sona. "Dilettantism Raises Its Head among Armenia's Diplomatic Corps." 1am [in Armenian], 2018. https://goo.gl/QrC4Pa

Hocking, Brian, Jan Melissen, Shaun Riordan, and PaulSharp. Futures for Diplomacy: Integrative Diplomacy in the 21st Century. Report No. 1. Netherlands Institute of International Relations 'Clingendael', 2012. https://www.clingendael.org/sites/default/files/pdfs/20121030_research_melissen.pdf

Karapetyan, Ruben. "Diplomacy without Foreign Policy." Radio Liberty, 2018. https://goo.gl/EBJtHL

Kelley, John Robert. "The New Diplomacy: Evolution of a Revolution." Diplomacy \& Statecraft 21, no. 2 (2010): 286-305.

Kleiner, Juergen. "The Inertia of Diplomacy." Diplomacy \& Statecraft 19, no. 2 (2008): 321-349. doi:10.1080/09592290802096380.

Kocharyan, Robert. Zhizn' i Svoboda: Avtobiographiya Eks-Prezidenta Armenii i Karabakha [Life and Freedom: Autobiography of the Former President of Armenia and Karabakh]. Moscow: Intellectual Literature, 2019.

Kopp, Harry, and CharlesGillespie. Career Diplomacy. Life and Work in the USForeign Service. Washington, DC: Georgetown University Press, 2008.

Lane, Ann. "Modernising the Management of British Diplomacy: Towards a Foreign Office Policy on Policy-Making?" Cambridge Review of International Affairs 20, no. 1 (2007): 179-193. doi:10.1080/ 09557570601155351. 
"Law on Diplomatic Service of the RA, 2001." Arlis.am [in Armenian]. https://goo.gl/qWDreR

Libaridian, Gerard. The Challenge of Statehood: Armenian Political Thinking since Independence. Watertown, MA: Blue Crane Books, 1999.

McCormick, James M. American Foreign Policy and Process. Itasca, IL: F. E. Peacock Publishers, Inc., 1998.

Minasyan, Sergey."Multi-Vectorism in the Foreign Policy of Post-Soviet Eurasian States."Demokratizatsiya 20, no. 3 (2012): 268-273.

Ministry of Foreign Affairs of the Republic of Armenia. "Press Conference, Answers of the Minister of Foreign Affairs of Armenia Edward Nalbandian during the Annual Press Conference on the Activities of the Foreign Ministry during 2013, 2014." 2017. https://goo.gl/rNoMSA

Ministry of Foreign Affairs of the Republic of Armenia. Report on the Activities of the Ministry of Foreign Affairs of the Republic of Armenia, 2013 [in Armenian], 2017. https://goo.gl/Vge2Tb

Ministry of Foreign Affairs of the Republic of Armenia, Embassies. “Diplomatic Directory, 2013.” 2017. https://goo.gl/2b73bg

Ministry of Foreign Affairs of the Republic of Armenia, Press Releases. "The Consultations of Senior Officials of MFA and Heads of Diplomatic Missions Were Held in Yerevan, 2014." 2017. https://goo. gl/RFkbjB

Ministry of Foreign Affairs of the Republic of Armenia. Press Releases, "Statement of the Minister of Foreign Affairs Edward Nalbandian on the Occasion of the Day of the RA Diplomats, 2014" [in Armenian], 2017. https://goo.gl/DDdHcs

Moses, Jonathon W., and Torbjorn Knutsen. "Inside out: Globalization and Reorganization of Foreign AffairsMinistries."CooperationandConflict36,no.4(2001):355-380.doi:10.1177/00108360121962506.

Mueller, Sherry L. "New Perspectives on Public Diplomacy." In The Theory and Practice of International Relations, 8th ed., edited by William Clinton Olson, 90-96. Englewood Cliffs, NJ: Prentice Hall, 1991.

Oskanian, Vartan. Ankakhutyan Chanaparhov: Pokr Yerkri Mets Martahravernery. Nakharari Oragrits [Through the Road of Independence: Big Challenges of a Small Country. From the Minister's Diary]. Yerevan: Civilitas Foundation, 2013.

Papazian, Taline. “From Ter-Petrosyan to Kocharian: Explaining Continuity in Armenian Foreign Policy, 1991-2003." Demokratizatsiya: The Journal of Post-Soviet Democratization 14, no. 2 (2006): 235-251. doi:10.3200/DEMO.14.2.235-251.

President.am, Press Releases. "Statement of President Sargsyan at the Gathering of the MFA Central Staff and Heads of the Armenian Diplomatic Representative and Consulates Abroad." 2008. https:// goo.gl/JjfXg

President.am, Statements and Messages of the President of the RA. “Excerpts from Serzh Sargsyan's Address at the Consultations with the Senior Staff of the RA Ministry of Foreign Affairs and the Heads of the Armenian Diplomatic Missions Abroad." 2011. https://goo.gl/BbYxpv

President.am. "Statement of President Sargsyan at the Annual Gathering of the MFA Senior Executive Staff and Heads of the Armenian Embassies and Consulates abroad." 2009. Accessed September 1, 2009. https://www.president.am/en/press-release/item/2009/09/01/news-679/.

Rana, Kishan. 21st Century Diplomacy. A Practitioner's Guide. London \& New York: Continuum International Publishing Group, 2011.

Rana, Kishan. Foreign Ministries: Change and Reform. Working Paper: 1-22. New Delhi: Foreign Service Institute, 2005.

Sargsyan, Zhanna. "Violations of Law in Foreign Ministry are Common." Hetq [Investigative Journalists] [in Armenian]. https://goo.gl/GvqAfu

Sarkesian, Sam, John Williams, and Stephen Cimbala. US National Security: Policymakers, Processes, and Politics. 4th ed. Boulder, CO: Lynne Rienner Publishers, 2008.

"Serzh Sargsyani nakhyntrakan tsragiry" ["The Election Platform of Serzh Sargsyan"], January 21, 2008. https://hetq.am/hy/article/31774/

Shougarian, Rouben. Does Armenia Need a Foreign Policy? London: Gomidas Institute, 2006.

Shougarian, Rouben. “We Have Not Resigned." 2008. https://www.azatutyun.am/a/1594959.html 
Ter-Matevosyan, Vahram, Anna Drnoian, Narek Mkrtchyan, and Tigran Yepremyan. "Armenia in the Eurasian Economic Union: Reasons for Joining and Its Consequences." Eurasian Geography and Economics 58, no. 3 (2017): 340-360. doi:10.1080/15387216.2017.1360193.

Ter-Petrossian, Levon. Armenia's Future Relations with Turkey, and the Karabakh Conflict, edited by A. Grigoryan. London and New York, Palgrave Macmillan, 2018.

Ter-Petrossian, Levon. "Entrani: Yeluytner, hodvatsner, hartsazruytsner" ["Selected Speeches, Articles, Interviews"]. Yerevan. Archives of the First President of the Republic of Armenia, 2006.

"The Constitution of the Republic of Armenia (with Amendments), 2005." President.am, 2017. https:// goo.gl/jnzMZE.

"The Decree of the President of the RA on the Coordination of the Common Foreign Policy of the RA Executive Bodies, 2000." 1st clause, Arlis.am [in Armenian], 2017. https://goo.gl/LXVTNR

"The RA Government Decree No. 325-N on Marking the Day of the Diplomats, 2012." Arlis.am [in Armenian], 2017. https://goo.gl/uGznG3

"The RA President Order NK-107-N on Instituting the Planning, Evaluation and Monitoring System of the RA Diplomatic Missions and Consulates, 2010." Addendum 1.2., Arlis.am [in Armenian], 2017. https://goo.gl/MCQ3a6 